\title{
Radiotherapy of primary cutaneous follicle center lymphoma: case report and review of literature
}

\author{
Romana Ceovic ${ }^{1 *}$, Ivana Jovanovic ${ }^{2}$, Kresimir Kostovic ${ }^{1}$, Jaka Rados ${ }^{1}$, Snjezana Dotlic ${ }^{3}$, Ivo Radman ${ }^{4}$, \\ Sandra Marinovic Kulisic ${ }^{1}$ and Davorin Loncaric ${ }^{1}$
}

\begin{abstract}
Primary cutaneous follicle center lymphoma is an indolent primary cutaneous B-cell lymphoma originating from the follicle center cells, composed of a combination of centrocytes (small and large cleaved cells) and centroblasts (large noncleaved cells) with a follicular, follicular/diffuse, or diffuse growth pattern. Lesions are mostly located on the head, neck and trunk. A case is presented of a 56-year-old male patient with primary cutaneous follicle center lymphoma, with lesions involving the skin of the back, shoulders, presternal area and right forearm. As the patient presented a disseminated cutaneous form of the disease that involved several anatomical regions, complete work-up was followed by superficial fractionated radiotherapy of eight fields in VI expositions, with total irradiation dose of 1400 cGy upon the following fields: right and left pectoral region, left and right shoulders, right suprascapular region, and proximal third of the right forearm. Total irradiation dose applied upon each field for the lesions located on the left and right side of the back was 1500 cGy. This therapy resulted in significant reduction of visible tumor. The patient was regularly followed up on outpatient basis for 12 months of radiotherapy, being free from local recurrence and systemic spread of the disease.
\end{abstract}

Keywords: Primary Cutaneous Follicle Center Lymphoma, Superficial, Fractionated Radiotherapy

\section{Background}

Primary cutaneous follicle center lymphoma (PCFCL) can be defined as neoplastic proliferation of the follicle germinal center cells limited to the skin. PCFCL is a primary cutaneous B-cell lymphoma composed of neoplastic B-cells with morphological and immunophenotypic properties of follicle center cells, usually a combination of centrocytes (small and large cleaved center cells) and a variable number of centroblasts (large noncleaved follicle center cells with prominent nucleoli). According to growth pattern, it is divided into follicular, diffuse and mixed pattern. This type of lymphoma is described as a separate entity in the WHO-EORTC classification of primary cutaneous lymphomas [1], as well as in the new WHO classification of hematopoietic and lymphoid tissue tumors [2]. The diagnosis of PCFCL is made in $11 \%$ of all patients with cutaneous lymphomas [1].

\footnotetext{
* Correspondence: romana.ceovic@zg.htnet.hr

'Department of Dermatology and Venereology, University Hospital Center

Zagreb and School of Medicine, Zagreb, Croatia

Full list of author information is available at the end of the article
}

All cutaneous lymphomas require complete work-up including staging in order to rule out extracutaneous lymphoma of similar morphology [3]. Disease staging includes physical examination, laboratory testing, chest $\mathrm{x}$-ray, ultrasonography (US) of lymph nodes and visceral organs, computed tomography (CT) of the chest, abdomen and pelvis, and bone marrow biopsy. Besides complete disease history, making an accurate diagnosis requires histopathology, immunophenotyping and molecular studies.

When extracutaneous disease has been excluded by complete work-up, the diagnosis of primary cutaneous lymphoma can be made [1,4]. Fluorodeoxyglucose-positron emission tomography (FDG-PET), recently increasingly employed, can be performed as an additional study, along with bone marrow biopsy [5,6]. As comparison of FDGPET and bone marrow biopsy findings showed no major differences in their accuracy and specificity, the authors concluded that FDG-PET could be used as an additional study to bone marrow biopsy, in the work-up of malignant lymphoma in particular [7].

Ciomed Central

(the article

(c) 2013 Ceovic et al.; licensee BioMed Central Ltd. This is an Open Access article distributed under the terms of the Creative Commons Attribution License (http://creativecommons.org/licenses/by/2.0), which permits unrestricted use, distribution, and reproduction in any medium, provided the original work is properly cited. 
The etiology of PCFCL remains unknown, however, association with Borrelia burgdorferi, hepatitis C or human herpesvirus 8 infection has been occasionally described [8-11]. In the majority of cases, adults of both sexes are affected, whereas PCFCL is rare in childhood [12]. Clinical picture is characterized by the occurrence of solitary or grouped erythematous papules, plaques and tumor lesions, mostly non-ulcerated. The lesions are usually localized in the head, neck and trunk areas, less frequently on lower extremities [13-15]. The lesions localized on the back were in the past known as Crosti lymphoma or reticulohistiocytoma of the back [14]. There is no strict differentiation in clinical picture and localization of follicular and diffuse PCFCL; however, the former are predominantly found in the head and neck region, and the latter on the trunk [16,17]. Generally, PCFCL is a localized disease rarely associated with extracutaneous dissemination [18].

The histopathologic picture of PCFCL varies depending on the duration, stage of lesion growth as revealed by biopsy specimen, and localization [15,19]. Most slides show nodular to diffuse infiltrates with normal epidermis. Minor and initial lesions contain a mixed picture of centrocytes, some centroblasts, and less reactive $\mathrm{T}$ cells. Large centrocytes are characteristic of PCFCL. Large neoplastic B-cells may resemble fibroblasts. Follicular growth can be clearly observed in minor and/or initial lesions. Well differentiated diffuse PCFCL lesions involve the entire dermis, frequently spreading to the subcutaneous adipose tissue. The lesions are characterized by proliferation of small, medium-sized and large cleaved cells (centrocytes) admixed with a variable number of large cells with morphological characteristics of centroblasts. Small reactive $\mathrm{T}$ lymphocytes are mostly intertwined with tumor cells. Histologic slide with biopsy specimen of a lesion with follicular growth pattern may mimick follicular extracutaneous lymphoma $[17,20]$. PCFCL with follicular growth is composed of nodular infiltrates in the dermis, usually with subcutaneous tissue involvement, characterizing the follicular growth basis. If present, neoplastic follicles show morphological abnormalities such as reduced or absent mantle cell zone, reduced or completely absent stained body macrophages, and monomorphous phenomenon without clearly delineated dark and light areals. Cytomorphologically, neoplastic follicles consist of small and large centrocytes linked to centroblasts, frequently mixed with small reactive lymphocytes. In some cases, both diffuse and follicular growth characteristics are found in the same tumor; residual follicles are seen on the infiltrate periphery, while diffuse growth predominates in the central part. The morphological variants of PCFCL showing nodules of medium-sized centrocytes mixed with centroblasts without prominent interfollicular infiltrate were earlier known as large-cell lymphocytoma [21,22].

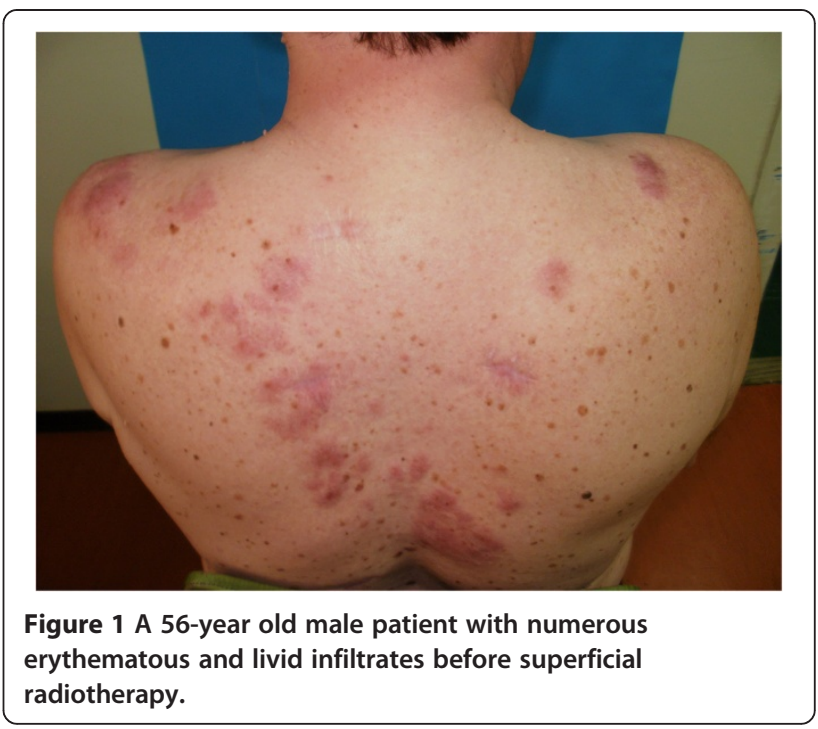

As the tumor lesion grows, neoplastic B lymphocytes also grow and replicate, while the number of reactive $T$ cells is on a decrease $[15,19]$. The stromal component is usually very pronounced.

In case of either diffuse or neoplastic PCFCL, neoplastic cells are positive for CD20 and CD79a B-cell markers. In most cases of PCFCL with diffuse growth characteristics, cells are CD10- and without a network of CD21 follicular dendritic cells in the background. In contrast, in PCFCL with follicular growth cells are positive for $\mathrm{CD} 10$ and Bcl6 markers [17,23-25]. The presence of small CD10+ and/ or Bcl-6+ clusters outside the neoplastic follicles may be occasionally seen [17]. This phenomenon caused by 'active migration' of neoplastic follicular cells from the follicles toward the interfollicular space and back, has been described in nodal follicular lymphomas [26]. Other markers

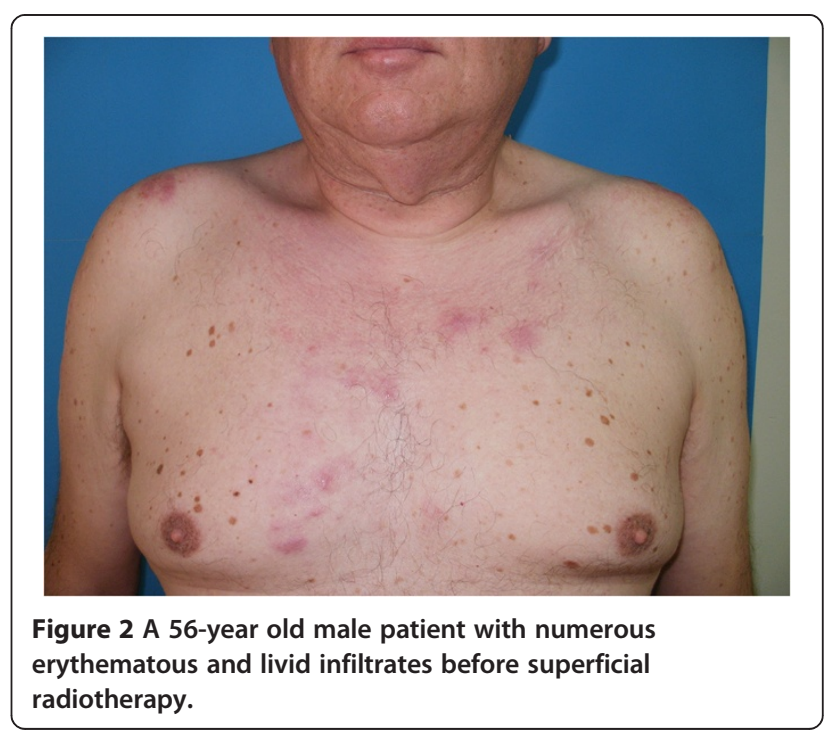


can be used to verify differentiation of the neoplastic cell germinal center, such as paired box gene (PAX)-5 gene and interferon regulatory factor (IRF) 8 , however, other B-cells are also positive for these markers [27]. On the slides with visible diffuse and follicular growth features, CD21+ follicular dendritic cells are located in the periphery of larger areals with a diffuse growth pattern. Residual network of CD21 follicular dendritic cells is mostly found within neoplastic follicles. Unlike nodal follicular lymphoma, expression of bcl-2 is generally rare $[17,27,28]$. Bcl-2 positive cells are infrequently found in PCFCL, localized within the follicular center in $10 \%-15 \%$ of cases and only rarely in the entire neoplastic population [17,27,29-35]. Multiple myeloma oncogene-1 (MUM-1) is positive in less than $30 \%$ of PCFCL cells [36]. Polyclonal plasma cells with no restriction of $\mathrm{K}$ and $\lambda$ chains are frequent in patients with cutaneous lymphoma [17,37].

In most cases, PCFCL shows monoclonal distribution of the $\mathrm{J}_{\mathrm{H}}$ gene, but also a reduced detection of this distribution by the PCR method. This might be, at least in part, due to the high number of somatic hypermutations characteristic of this tumor. Somatic hypermutations of variable heavy and light chains can be observed, confirming this lymphoma to originate from the follicular center cells [38,39]. Numerous literature data clearly demonstrate that PCFCL generally is not associated with $\mathrm{t}$ $(14 ; 18)$ translocation $[17,27,40-44]$. The presence of $t$ $(14 ; 18)$ translocation is characteristic of systemic follicular lymphomas and part of systemic diffuse large cell B-lymphomas $[25,28,29,40]$.

Inactivity of the p15 and p16 tumor suppressor genes may be detected in 10\%-30\% of cases [45]. In most patients with solitary or multiple lesions generally localized on the head and trunk, therapy of choice is radiotherapy based on histologic classification according to the growth pattern and number of blast cells, and the prognosis is good in these patients [1,4,13-15,46-51]. Radiotherapy is first-line therapy also for tumor lesions with histologically predominant large cleaved cells [48,50,52-55]. Skin relapses, seen in $20 \%$ of patients, which do not readily suggest disease progression, can also be treated with radiotherapy [56]. In case of localized skin lesions, excision of tumor lesions should be considered, followed by radiotherapy of the operative field and adjacent skin [15]. Chemotherapy is indicated for extensive and spread skin lesions and in patients developing extracutaneous disease $[17,52]$. Systemic and intralesional interferon $\alpha$, or in combination with other therapeutic procedures, can also be taken in consideration [57-61].

Recent studies report on therapeutic results recorded with systemic or intralesional anti-CD20 antibody therapy in PCFCL patients [62-68]. Rituximab (anti-CD20 antibody) can be therapeutically combined with systemic

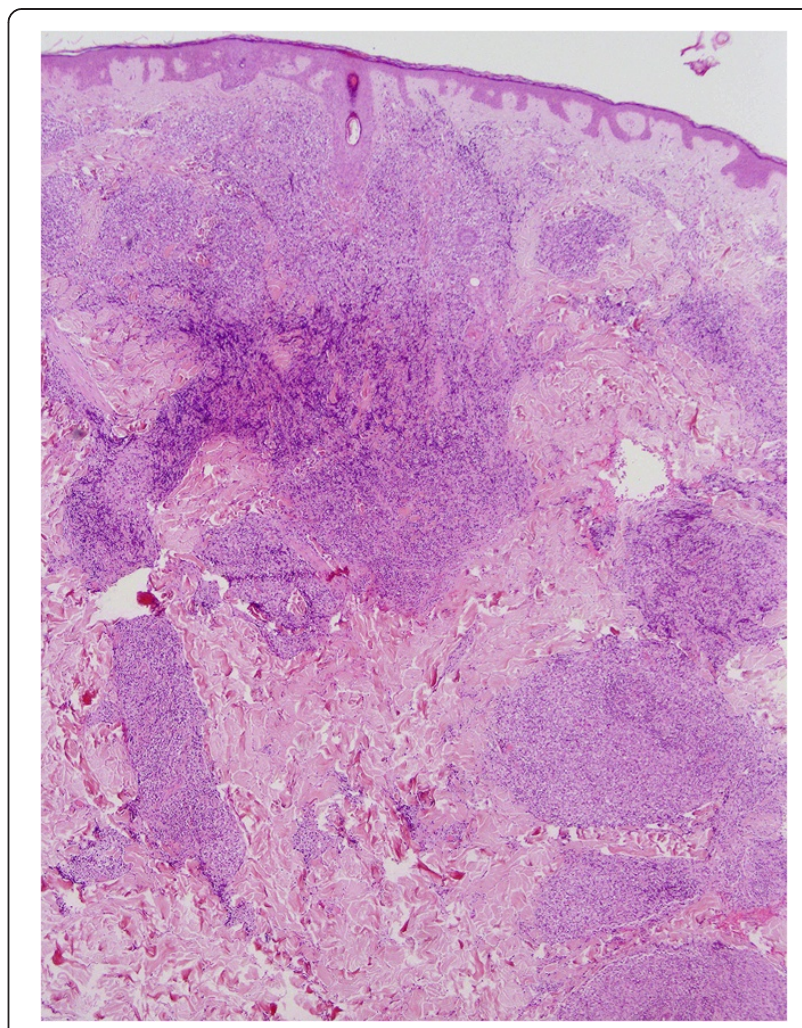

Figure 3 The epidermis is preserved, with diffuse and nodular infiltrates of lymphoid cells. (H\&E, magnification 40X).

chemotherapy in patients with generalized skin disease, extracutaneous disease, or relapsing cutaneous lesions [69]. Taking the growth pattern, blast cell count, and presence of solitary or multiple cutaneous lesions into consideration, PCFCL has a good prognosis with 5-year survival of about $95 \%[4,13-15,17,29,46-49]$. There is no substantial prognosis difference between tumor lesions with a follicular growth pattern and tumor lesions with

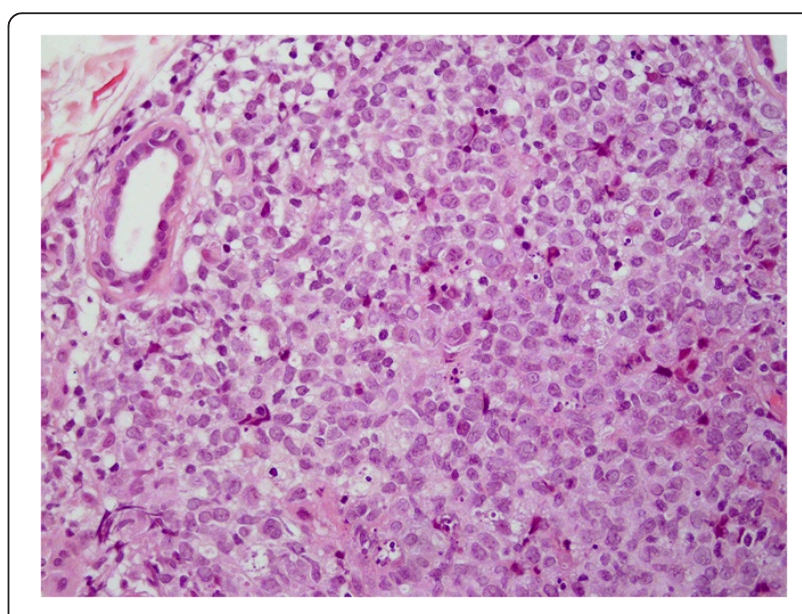

Figure 4 The infiltrate is composed of atypical, medium-sized and focally large lymphatic cells. (H\&E, magnification 400X). 

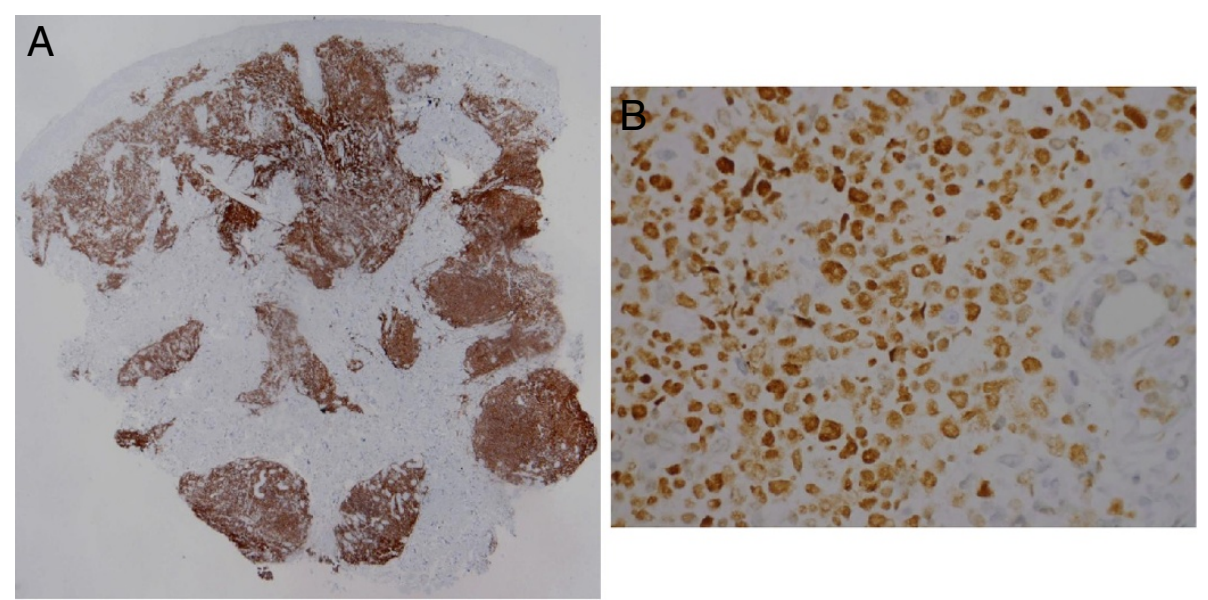

Figure 5 Immunohistochemical staining for CD20 demonstrates diffusely positive reaction in tumour cells (A: IHC, CD20, magnification 20x), coexpressing BCL6 (B: IHC, BCL6, magnification 400X).

diffuse growth pattern $[1,4]$, but some studies indicate that poorer prognosis should be expected in PCFCL cases with diffuse growth pattern, pronounced bcl-2 expression and histologically visible large cells [70].

In spite of the possible occurrence of local relapses, seen in some $20 \%$ of cases, extracutaneous dissemination of the disease is uncommon. There are only rare cases of disease dissemination to the central nervous system [70].

\section{Case presentation}

A 56-year-old male patient presented to our Department for cutaneous lesions that had first appeared four years before. Clinical picture included numerous erythematous and erythematous-livid infiltrates, $2-8 \mathrm{~cm}$ in diameter, on his upper back, shoulders, in the presternal region and in the proximal third of his right forearm [Figures 1 and 2]. There was no enlargement of the palpable lymph nodes and the patient denied any subjective discomforts of pain or itch. He had been treated for type 2 diabetes

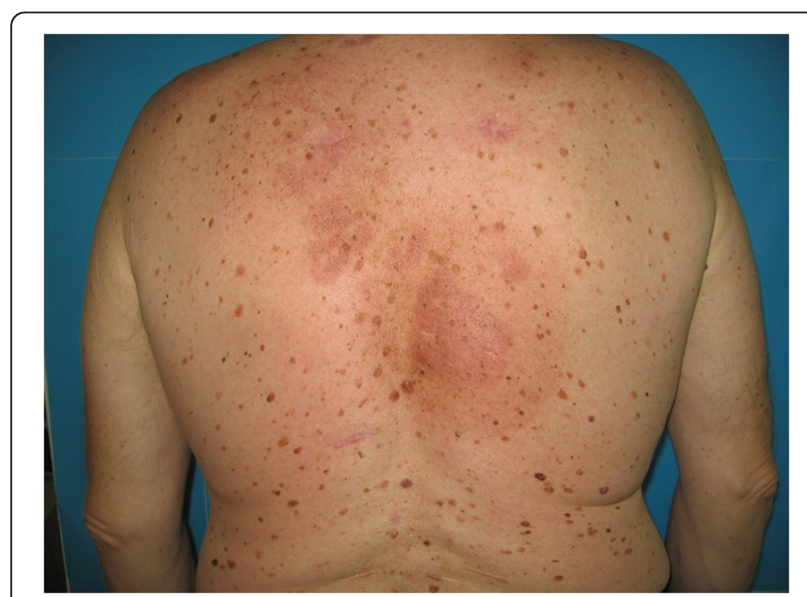

Figure 6 Post-radiotherapy appearance. mellitus and arterial hypertension for years and regulary checked for multipli naevi pigmentosi on the trunk.

Laboratory findings: complete blood count, urine, blood glucose, liver enzymes, bilirubin, urea, creatinine, lipid profile, creatine kinase, lactate dehydrogenase, C-reactive protein, protein electrophoresis, immunoglobulins, and serum $\mathrm{Cu}$ were within the reference values. Serology for hepatitis C and B viruses and Borrelia burgdorferi [5-8], and HIV-ELISA produced negative findings.

Biopsy specimens were obtained from lesions on the left shoulder, the back and the right shoulder. Histopathology of all three specimens revealed superficially regular, preserved epidermis and diffuse full-depth lymphocyte infiltration of the excised dermis [Figure 3]. In the deep dermis, there was abundant lymphocytic infiltrate with the formation of follicular germinal center and the surrounding 'mantle zone'. The infiltrate was composed of atypical, medium-sized and focally large lymphatic cells [Figure 4].

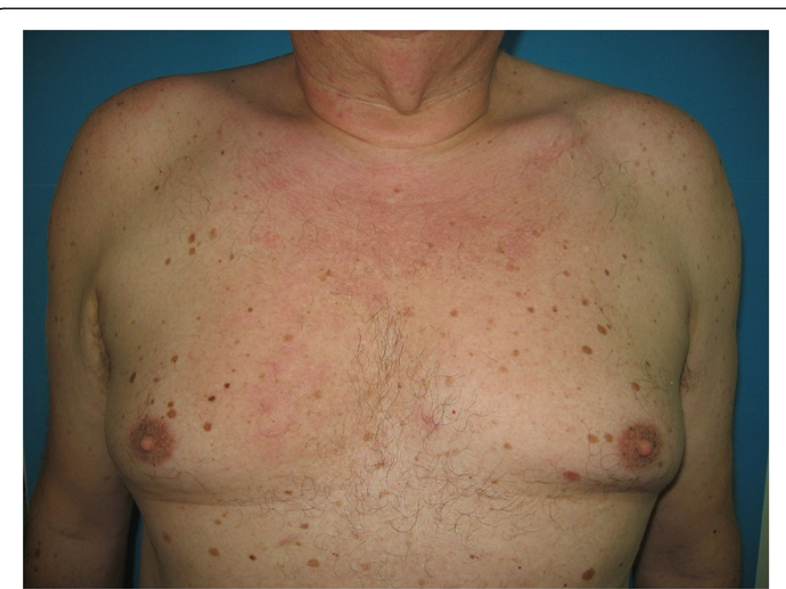

Figure 7 Post-radiotherapy appearance. 
Immunohistochemistry showed the atypical, mediumsized and focally large lymphatic cells to be CD20+, bcl-6+, bcl-2 weakly positive, CD10-, MUM1-, CD3- and CD5- [Figure 5A,B]. Staining for $\kappa$ and $\lambda$ chains demonstrated rare polyclonal plasma cells peripherally. Staining for CD21 showed the follicular dendritic network to be preserved and focally extended.

Clonal B lymphocyte population was demonstrated by molecular analysis using the PCR method with analysis of rearrangement in the gene for immunoglobulin heavy chain and the gene for immunoglobulin light chain of kappa type (IgK).

Considering the histologic picture and verified clonality, the finding corresponded to the skin infiltration with B-immunophenotype lymphoma, requiring further exclusion of extracutaneous lymphoma $[1,3,4]$.

The patient was referred to a hematologist; based on hematologic examination and the findings available, the hematologist suggested ruling out systemic disease and recommended bone marrow biopsy and multi-slice computed tomography (MSCT).

Bone marrow biopsy revealed no evidence of tumor.

MSCT of the thorax, abdomen and pelvis showed no lymphadenopathy, however, visualizing multiple concrements up to $8 \mathrm{~mm}$ in size in the cholecyst.

Upon complete work-up, and considering the histologic picture, verified clonality and exclusion of extracutaneous spread of the disease, the finding was consistent with the picture of PCFCL.

As our patient had a disseminated cutaneous form of the disease involving multiple anatomic regions, we decided on the use of superficial fractionated radiotherapy [1,4,13-15,46-51], administered upon eight fields in VI expositions, with total irradiation dose of $1400 \mathrm{cGy}$, on the following irradiation fields: left and right pectoral region, left and right shoulder, right suprascapular region, and proximal third of the right forearm. Total dose received per field upon lesions on the left and right side of the back was 1500 cGy. This therapy resulted in significant reduction of visible tumor [Figures 6 and 7 . Post-radiotherapy skin appearance]. The patient was regularly followed up for 12 months following radiotherapy and remained free from local relapse or extracutaneous dissemination of the disease. Staging of the disease can be repeated in case of relapse or every 12 months (heart and lung $\mathrm{x}$-ray is usually repeated every $2-3$ years).

\section{Conclusion}

In the patient presented, the diagnosis of PCFCL with follicular growth pattern was made by complete work-up and exclusion of systemic disease. Although it is an indolent B-cell lymphoma, appropriate approach to the patient and complete diagnostic work-up are necessary as in all cutaneous lymphomas. Close collaboration of specialists in dermatology, pathology, cytology and hematology is of utmost importance to reach an accurate diagnosis, to perform proper disease staging, and to choose the most suitable therapeutic modality.

Of the known therapeutic procedures, we decided to use superficial fractionated radiotherapy upon eight fields, which led to the significant reduction of visible tumor.

Patients with this type of cutaneous lymphoma have good prognosis, with the expected 5-year survival of $95 \%$ and rare systemic disease development. Skin relapses are reported in $20 \%$ of cases and are treated with radiotherapy. Our patient has been on regular follow up for possible skin relapses or extracutaneous disease dissemination.

\section{Consent}

Written informed consent was obtained from the patient for publication of this Case report and any accompanying images. A copy of the written consent is available for review by the Editor-in-Chief of this journal.

\section{Competing interests}

The author(s) declare that they have no competing interests.

\section{Authors' contributions}

$\mathrm{RC}$, IJ and KK are doctors who were treating patient from the first day he came to the Clinic. They have made substantial contributions to his treatment, acquisition of data, analysis and interpretation of data. They have been involved in drafting the manuscript or revising it critically for important intellectual content; and have given final approval of the version to be published. JR,SD and DL are dermatopathologists who made histopathology and immunohistochemistry, SMK was patient's leading doctor during hospitalization, IR is hematologist who have made substantial contributions to conception of diagnostic procedures, analysis of data and treatmant. All authors read and approved the final manuscript.

\section{Authors' information}

Assist. Professor Romana Ceovic is Head of the Department of Dermatological Oncology at the University Hospital, Zagreb, Croatia and Head of Refferal Center for Dermatooncology in Croatia. Her current interests include radiotherapy of skin tumors.

\section{Author details}

'Department of Dermatology and Venereology, University Hospital Center Zagreb and School of Medicine, Zagreb, Croatia. ${ }^{2}$ Department of Dermatology and Venereology, Dr. Josip Benčević General Hospital, Slavonski Brod, Croatia. ${ }^{3}$ Department of Pathology, University Hospital Center Zagreb and School of Medicine, Zagreb, Croatia. ${ }^{4}$ Department of Hematology, University Hospital Center Zagreb and School of Medicine Zagreb, Zagreb, Croatia.

Received: 16 June 2013 Accepted: 17 June 2013 Published: 20 June 2013

\section{References}

1. Willemze R, Jaffe ES, Burg G, Cerroni L, Berti E, Swerdlow SH, Ralfkiaer E, Chimenti S, Diaz-Perez JL, Duncan LM, Grange F, Harris NL, Kempf W, Kerl H, Kurrer M, Knobler R, Pimpinelli N, Sander C, Santucci M, Sterry W, Vermeer $\mathrm{MH}$, Wechsler J, Whittaker S, Meijer CJ: WHO-EORTC classification of cutaneous lymphomas. Blood 2005, 105:3768-3785.

2. Willemze R, Swerdlow SH, Harris NL, Vrgier B: Primary cutaneous follicle center lymphoma. In Classification of Tumours of Haematopoietic and Lymphoid Tissues. 2nd edition. Edited by Swerdlow SH. Lyon: IARC Press; 2008:227-228 
3. Senff NJ, Kluin- Nelemans JC, Willemze R: Results of bone marrow examination in 275 patients with histological features that suggest an indolent type of cutaneous B-cell lymphoma. Br J Haematol 2008, 142:52-56.

4. Fink-Puches R, Zenahlik P, Back B, Smolle J, Kerl H, Cerroni L: Primary cutaneous lymphomas: applicability of current classification schemes (European Organisation for Research and Treatment of Cancer, World Health Organisation) based on clinicopathologic features observed in a large group of patients. Blood 2002, 99:800-805.

5. Pelosi E, Penna D, Deandreis D, Chiappella A, Skanjeti A, Vitolo U, Bisi G: FDG-PET in the detection of bone marrow disease in Hodgkin's disease and aggressive non-Hodgkin's lymphoma and its impact on clinical management. Q J Nucl Med Mol Imaging 2008, 52:9-16.

6. Kuo PH, McClennan BL, Carlson K, Wilson LD, Edelson RL, Heald PW, Girardi M: FDG-PET/CT in the evaluation of cutaneous T-cell lymphoma. Mol Imaging Biol 2008, 10:74-81.

7. Pelosi E, Penna D, Douroukas A, Bellò M, Amati A, Arena V, Passera R, Bisi G: Bone marrow disease detection with FDG-PET/CT and bone marrow biopsy during the staging of malignant lymphoma: results from a large multicentre study. Q J Nucl Med Mol Imaging 2011, 55:469-475.

8. Cerroni L, Zöchling N, Pütz B, Kerl H: Infection by Borrelia burgdorferi and cutaneous B-cell lymphoma. J Cutan Pathol 1997, 24:457-461.

9. Goodlad JR, Davidson MM, Hollowood K, Ling C, MacKenzie C, Christie I, Batstone P, Ho-Yen D: Primary cutaneous B-cell lymphoma and Borrelia burgdorferi infection in patients from the highlands of Scotland. Am J Surg Pathol 2000, 24:1279-1285.

10. Zöchling N, Pütz B, Wolf P, Kerl H, Cerroni L: Human herpesvirus 8-specific DNA sequences in primary cutaneous B-cell lymphomas. Arch Dermatol 1998, 134:246-247.

11. Viguier M, Rivet J, Agbalika F, Kerviler E, Brice P, Dubertret L, Bachelez H: B-cell lymphomas involving the skin associated with hepatitis $C$ virus infection. Int J Dermato/ 2002, 41:577-582

12. Ghislanzoni M, Gambini D, Perrone T, Alessi E, Berti E: Primary cutaneous follicular center cell lymphoma of the nose with maxillary sinus involvement in a pediatric patient. J Am Acad Dermatol 2005, 52:s73-s75.

13. Willemze R, Meijer CJ, Sentis HJ, Scheffer E, van Vloten WA, Toonstra J, van der Putte SC: Primary cutaneous large cell lymphomas of follicular center origin. J Am Acad Dermatol 1987, 16:518-526.

14. Berti E, Alessi E, Caputo R, Gianotti R, Delia D, Vezzoni P: Reticulohistiocytoma of the dorsum. J Am Acad Dermatol 1988, 19:259-272.

15. Santucci M, Pimpinelli N, Arganini L: Primary cutaneous B-cell lymphoma: a unique type of low grade lymphoma. Cancer 1991, 67:2311-2326.

16. Pimpinelli N, Santucci M, Carli P, Paglierani M, Bosi A, Moretti S, Giannotti B: Primary cutaneous follicular center cell lymphoma: clinical and histological aspects. Curr Probl Dermatol 1990, 19:203-220.

17. Cerroni L, Arzberger E, Pütz B, Höfler G, Metze D, Sander CA, Rose C, Wolf P, Rütten A, McNiff JM, Kerl H: Primary cutaneous follicle center cell lymphoma with follicular growth pattern. Blood 2000, 95:3922-3928.

18. Groves FD, Linet MS, Travis LB, Devesa SS: Cancer surveillance series: non-Hodgkin's lymphoma incidence by histologic subtype in the United States from 1978 through 1995. J Natl Cancer Inst 2000, 92:1240-1251.

19. Willemze R, Meijer CJ, Scheffer E, Kluin PM, Van Vloten WA, Toonstra J, Van der Putte SC: Diffuse large cell lymphomas of follicular center cell origin presenting in the skin. A clinicopathologic and immunologic study of 16 patients. Am J Pathol 1987, 126:325-333.

20. Nathwani BN, Winberg CD, Diamond LW, Bearman RM, Kim H: Morphologic criteria for the differentiation of follicular lymphoma from florid reactive follicular hyperplasia: a study of 80 cases. Cancer 1981, 48:1794-1806.

21. Englisch JSC, Smith NP, Spaull J, Wilson Jones E, Winkelmann RK: Large cell lymphocytoma: a clinicopathological study. Clin Exp Dermatol 1989, 14:181-185

22. Winkelmann RK, Dabski K: Large cell lymphocytoma: follow up immunopathology studies, and comparison to cutaneous follicular and Crosti lymphoma. Arch Dermatol Res 1987, 279:581-s87.

23. Leinweber B, Colli C, Chott A, Kerl H, Cerroni L: Differential diagnosis of cutaneous infiltrates of B lymphocytes with follicular growth pattern. Am J Dermatopathol 2004, 26:4-13.

24. Hoefnagel JJ, Vermeer MH, Jansen PM, Fleuren GJ, Meijer CJ, Willemze R: $\mathrm{BCl}-2, \mathrm{BCl}-6$ and CD10 expression in cutaneous B-cell lymphoma: further support for a follicle centre cell origin and differential diagnostic significance. Br J Dermatol 2003, 149:1183-1191.
25. Kim BK, Surti U, Pandya AG, Swerdlow SH: Primary and secondary cutaneous diffuse large B-cell lymphoma. Am J Surg Pathol 2003, 27:356-364

26. Dogan A, Du MQ, Aiello A, Diss TC, Ye HT, Pan LX, Isaacson PG: Follicular lymphomas contain a clonally linked but phenotypically distinct neoplastic B-cell population in the interfollicular zone. Blood 1998 91:4708-4714

27. Cerroni L, Volkenandt M, Rieger E, Soyer HP, Kerl H: Bcl-2 protein expression and correlation with the interchromosomal 14;18 translocation in cutaneous lymphomas and pseudolymphomas. J Invest Dermatol 1994, 102:231-235.

28. Geelen FA, Vermeer MH, Meijer CJ, Van der Putte SC, Kerkhof E, Kluin PM, Willemze RJ: Bcl-2 protein expression in primary cutaneous large B-cell lymphoma is site-related. Clin Oncol 1998, 16:2080-2085.

29. Goodlad JR, Krajewski AS, Batstone PJ, McKay P, White JM, Benton EC, Kavanagh GM, Lucraft HH, Scotland and Newcastle Lymphoma Group: Primary cutaneous follicular lymphoma: a clinicopathologic and molecular study of 16 cases in support of a distinct entity. Am J Surg Pathol 2002, 26:733-741.

30. Mirza I, Macpherson N, Paproski S, Gascoyne RD, Yang B, Finn WG, Hsi ED: Primary cutaneous follicular lymphoma: an assessment of clinical, histopathologic, immunophenotypic, and molecular features. J Clin Oncol 2002, 20:647-655.

31. Lawnicki LC, Weisenburger DD, Aoun P, Chan WC, Wickert RS, Greiner TC: The $t(14 ; 18)$ and $b c l-2$ expression are present in a subset of primary cutaneous follicular lymphoma: association with lower grade. Am J Clin Pathol 2002, 118:765-772.

32. Bachmeyer $C$, Khosrotehrani K, Moguelet $P$, Aractingi S: Primary cutaneous follicular B-cell lymphoma arising at the site of radiotherapy for breast cancer. Br J Dermatol 2007, 156:198-199.

33. De Leval L, Harris NL, Longtine J, Ferry JA, Duncan LM: Cutaneous B-cell lymphomas of follicular and marginal zone types: use of Bcl-6, CD10, $\mathrm{BCl}-2$, and CD21 in differential diagnosis and classification. Am J Surg Pathol 2001, 25:732-741.

34. Rijlaarsdam JU, Meijer CJ, Willemze R: Differentiation between lymphadenosis benigna cutis and primary cutaneous follicular center cell lymphomas. A comparative clinicopathologic study of 57 patients. Cancer 1990, 65:2301-2306.

35. Triscott JA, Ritter JH, Swanson PE, Wick MR: Immunoreactivity for bcl-2 protein in cutaneous lymphomas and lymphoid hyperplasias. J Cutan Pathol 1995, 22:2-10.

36. Kodama K, Massone C, Chott A, Metze D, Kerl H, Cerroni L: Primary cutaneous large B-cell lymphomas: clinicopathologic features, classification, and prognostic factors in a large series of patients. Blood 2005, 106:2491-2497.

37. Garcia CF, Weiss LM, Warnke RA, Wood GS: Cutaneous follicular lymphoma. Am J Surg Pathol 1986, 10:454-463.

38. Aarts WM, Willemze R, Bende RJ, Meijer CJ, Pals ST, van Noesel CJ, Aarts WM, Willemze R, Bende RJ, Meijer CJ, Pals ST, van Noesel CJ: VH gene analysis of primary cutaneous B-cell lymphomas: evidence for ongoing somatic hypermutation and isotype switching. Blood 1998, 92:3857-3864

39. Gellrich S, Rutz S, Golembowski S, Jacobs C, von Zimmermann M, Lorenz P, Audring $H$, Muche M, Sterry W, Jahn S: Primary cutaneous follicle center cell lymphomas and large B cell lymphomas of the leg descend from germinal center cells: a single cell polymerase chain reaction analysis. J Invest Dermatol 2001, 117:1512-1520.

40. Franco R, Fernandez-Vazquez A, Rodriguez-Peralto JL, Bellas C, López-Ríos F, Sáez A, Villuendas R, Navarrete M, Fernandez I, Zarco C, Piris MA: Cutaneous follicular B-cell lymphoma: description of a series of 18 cases. Am J Surg Pathol 2001, 25:875-883.

41. Child FJ, Russell-Jones R, Woolford AJ, Calonje E, Photiou A, Orchard G, Whittaker SJ: Absence of the $t(14 ; 18)$ chromosomal translocation in primary cutaneous B-cell lymphoma. Br J Dermatol 2001, 144:735-744.

42. Streubel B, Scheucher B, Valencak J, Huber D, Petzelbauer P, Trautinger F, Weihsengruber F, Mannhalter C, Cerroni L, Chott A: Molecular cytogenetic evidence of $t(14 ; 18)(I G H ; B C L 2)$ in a substantial proportion of primary cutaneous follicle center lymphomas. Am J Surg Pathol 2006, 30:529-536.

43. Kim BK, Surti U, Pandya A, Cohen J, Rabkin MS, Swerdlow SH: Clinicopathologic, immunophenotypic, and molecular cytogenetic fluorescence in situ hybridization analysis of primary and secondary cutaneous follicular lymphomas. Am J Surg Pathol 2005, 29:69-82. 
44. Delia D, Borrello MG, Berti E, Pierotti MA, Biassoni D, Gianotti R, Alessi E, Rizzetti MG, Caputo R, Della Porta G: Clonal immunoglobulin gene rearrangements and normal T-cell receptor, bcl-2, and c-myc genes in primary cutaneous B-cell lymphomas. Cancer Res 1989, 49:4901-4905.

45. Child FJ, Scarisbrick JJ, Calonje E, Orchard G, Russell-Jones R, Whittaker SJ: Inactivation of tumor suppressor genes p15(INK4b) and p16(INK4a) in primary cutaneous B cell lymphoma. J Invest Dermatol 2002, 118:941-948.

46. Willemze R, Kerl H, Sterry W, Berti E, Cerroni L, Chimenti S, Diaz-Peréz JL, Geerts ML, Goos M, Knobler R, Ralfkiaer E, Santucci M, Smith N, Wechsler J, van Vloten WA, Meijer CJ: EORTC classification of primary cutaneous lymphomas: a proposal from the Cutaneous Lymphoma Study Group of the European Organisation for Research and Treatment of Cancer. Blood 1997, 90:354-371.

47. Grange F, Hedelin G, Joly P, Beylot-Barry M, D'Incan M, Delaunay M, Vaillant L, Avril MF, Bosq J, Wechsler J, Dalac S, Grosieux C, Franck N, Esteve E, Michel C, Bodemer C, Vergier B, Laroche L, Bagot M: Prognostic factors in primary cutaneous lymphomas other than mycosis fungoides and the Sézary syndrome. The French Study Group on Cutaneous Lymphomas Blood 1999, 93:3637-3642.

48. Rijlaarsdam JU, Toonstra J, Meijer OW, Noordijk EM, Willemze R: Treatment of primary cutaneous B-cell lymphomas of follicle center cell origin: a clinical follow-up study of 55 patients treated with radiotherapy or polychemotherapy. J Clin Oncol 1996, 14:549-555.

49. Pimpinelli N, Santucci M, Bosi A, Moretti S, Vallecchi C, Messori A, Giannotti B: Primary cutaneous follicular centre-cell lymphoma: a lymphoproliferative disease with favourable prognosis. Clin Exp Dermatol 1989, 14:12-19.

50. Piccinno $R$, Caccialanza M, Berti E: Dermatologic radiotherapy of primary cutaneous follicle center cell lymphoma. Eur J Dermatol 2003, 13:49-52.

51. Senff NJ, Noordijk EM, Kim YH, Bagot M, Berti E, Cerroni L, Dummer R, Duvic M, Hoppe RT, Pimpinelli N, Rosen ST, Vermeer MH, Whittaker S, Willemze R, European Organization for Research and Treatment of Cancer; International Society for Cutaneous Lymphoma: European Organization for Research and Treatment of Cancer and International Society for Cutaneous Lymphoma consensus recommendations for the management of cutaneous B-cell lymphomas. Blood 2008, 112:1600-1609.

52. Grange F, Bekkenk MW, Wechsler J, Meijer CJ, Cerroni L, Bernengo M, Bosq J, Hedelin G, Fink Puches R, van Vloten WA, Joly P, Bagot M, Willemze R: Prognostic factors in primary cutaneous large B-cell lymphomas: a European multicenter study. J Clin Oncol 2001, 19:3602-3610.

53. Bekkenk MW, Vermeer MH, Geerts ML, Noordijk EM, Heule F, van Voorst Vader PC, van Vloten WA, Meijer CJ, Willemze R: Treatment of multifocal primary cutaneous B-cell lymphoma: a clinical follow-up study of 29 patients. J Clin Oncol 1999, 17:2471-2478.

54. Pimpinelli $N$, Vallecchi C: Local orthvolt radiotherapy in primary cutaneous B- cell lymphomas; results in series of 115 patients. Skin Cancer 1999, 14:219-224.

55. Smith BD, Glusac EJ, McNiff JM, Smith GL, Heald PW, Cooper DL, Wilson LD: Primary cutaneous B-cell lymphoma treated with radiotherapy: a comparison of the European Organization for Research and Treatment of Cancer and the WHO classification systems. J Clin Oncol 2004, 22:634-639.

56. Senff NJ, Hoefnagel JJ, Neelis KJ, Vermeer MH, Noordijk EM, Willemze R, Dutch Cutaneous Lymphoma Group: Results of radiotherapy in 153 primary cutaneous B-cell lymphomas classified according to the WHOEORTC classification. Arch Dermatol 2007, 143:1520-1526.

57. Parodi A, Micalizzi C, Rebora A: Intralesional natural interferon a in the treatment of Crosti' s lymphoma (primary cutaneous B follicular centrecell lymphoma): report of four cases. J Dermatol Treatm 1996, 7:105-107.

58. Cerroni L, Peris K, Torlone G, Chimenti S: Use of recombinant interferon a$2 \mathrm{a}$ in the treatment of cutaneous lymphomas of T- and B-cell lineage. In Basic Mechanisms of Physiologic and Aberrant Lymphoproliferation in the Skin. 265th edition. Edited by Lambert WC, Giannotti B, van Vloten WA. New York: Plenum Press; 1994:545-551.

59. Trent JT, Romanelli P, Kerdel FA: Topical targetin and intralesional interferona for cutaneous lymphoma of the scalp. Arch Dermato/ 2002, 138:1421-1423.

60. Sangfelt O, Erickson S, Castro J, Heiden T, Einhorn S, Grandér D: Induction of apoptosis and inhibition of cell growth are independent responses to interferon-alpha in hematopoietic cell lines. Cell Growth Differ 1997, 8:343-352.

61. Sangfelt O, Erickson S, Grander D: Mechanisms of interferon-induced cell cycle arrest. Front Biosci 2000, 5:479-487.
62. Heinzerling LM, Urbanek M, Funk JO, Peker S, Bleck O, Neuber K, Burg G, von Den Driesch P, Dummer R: Reduction of tumor burden and stabilization of disease by systemic therapy with anti-CD20 antibody (rituximab) in patients with primary cutaneous B-cell lymphoma. Cancer 2000, 89:1835-1844.

63. Schmook T, Stockfleth E, Lischner S, Gahn B, Christophers E, Hauschild A: Remarkable remission of a follicular lymphoma treated with rituximab and polychemotherapy (CHOP). Clin Exp Dermatol 2003, 28:31-33.

64. Paul T, Radny P, Kröber SM, Paul A, Blaheta HJ, Garbe C: Intralesional rituximab for cutaneous B-cell lymphoma. Br J Dermatol 2001, 144:1239-1243.

65. Heinzerling L, Dummer R, Kempf W, Schmid MH, Burg G: Intralesional therapy with anti-CD20 monoclonal antibody rituximab in primary cutaneous B-cell lymphoma. Arch Dermatol 2000, 136:374-378.

66. Kennedy GA, Blum R, McCormack C, Prince HM: Treatment of primary cutaneous follicular centre lymphoma with rituximab: a report of two cases. Australas J Dermatol 2004, 45:34-37.

67. Fink-Puches R, Wolf $\boxplus$, Zalaudek I, Kerl H, Cerroni L: Treatment of primary cutaneous B-cell lymphoma with rituximab. J Am Acad Dermatol 2005, 52:847-853.

68. Fierro MT, Savoia P, Quaglino P, Novelli M, Barberis M, Bernengo MG: Systemic therapy with cyclophosphamide and anti-CD20 antibody (rituximab) in relapsed primary cutaneous B-cell lymphoma: a report of 7 cases. J Am Acad Dermatol 2003, 49:281-287.

69. Grange F, Petrella T, Beylot-Barry M, Joly P, D'Incan M, Delaunay M, Machet L, Avril MF, Dalac S, Bernard P, Carlotti A, Esteve E, Vergier B, Dechelotte P, Cassagnau E, Courville P, Saiag P, Laroche L, Bagot M, Wechsler J: Bcl-2 protein expression is the strongest independent prognostic factor of survival in primary cutaneous large B-cell lymphomas. Blood 2004, 103:3662-3668.

70. Bekkenk MW, Postma TJ, Meijer CJ, Willemze R: Frequency of central nervous system involvement in primary cutaneous B-cell lymphoma. Cancer 2000, 89:913-919.

doi:10.1186/1748-717X-8-147

Cite this article as: Ceovic et al.: Radiotherapy of primary cutaneous follicle center lymphoma: case report and review of literature. Radiation Oncology 2013 8:147.

\section{Submit your next manuscript to BioMed Central and take full advantage of:}

- Convenient online submission

- Thorough peer review

- No space constraints or color figure charges

- Immediate publication on acceptance

- Inclusion in PubMed, CAS, Scopus and Google Scholar

- Research which is freely available for redistribution

Submit your manuscript at www.biomedcentral.com/submit
C) BioMed Central 